\title{
Response of Fertility Dose in Citronella (Cymbopogon winterianus L.) Intercropping with Mustard (Brassica juncea)
}

\author{
Neeraj Kumar ${ }^{*}$, Mayank Kumar ${ }^{2}$, Arjun Patel $^{2}$, A.K. Srivastava ${ }^{2}$ and Shasank Rajput ${ }^{2}$ \\ ${ }^{1}$ Chandra Shekar Azad University of Agriculture and Technology, \\ Kanpur - 208 002, Uttar Pradesh, India \\ ${ }^{2}$ Narendra Deva University of Agriculture and Technology, \\ Faizabad - 224 229, Uttar Pradesh, India \\ *Corresponding author
}

\section{A B S T R A C T}

Keywords

Fertility, Intercropping, Mustard, Kanpur.

Article Info

Accepted:

23 June 2017

Available Online:

10 August 2017
The present experiment was conducted during rabi season, 2014-15 at students Instructional Farm (SIF), C.S. Azad University of Agriculture and Technology, Kanpur with an object to find out suitable and economical combination of rabi intercrops with citronella (Cymbopogon winterianus L.).The experiment was laid out in completely randomize design with 09 treatment of cropping systems with different combination [sole citronella, sole Mustard, citronella + Mustard (100\% RDF), citronella + Mustard (75\% RDF), citronella + Mustard (50\% RDF) were replicated. Soil treatments with $100 \%$ RDF treated as control.

\section{Introduction}

The soil of experimental field was slightly alkaline with $8.09 \mathrm{pH}$ and $0.21 \mathrm{EC}$. The soil is low in organic carbon and low in available nitrogen $(260 \mathrm{~kg} / \mathrm{ha})$, medium in available phosphorus (17.55kg/ha) and medium in potash $(175 \mathrm{~kg} / \mathrm{ha})$. The citronella crop (cv. Bio-13) was transplanted in 30 July, 2010 at $60 \times 60 \mathrm{~cm}$. The rabi crop Mustard (cv. Urvasi) was sown 19 October 201414 at $40 \mathrm{x}$ $20 \mathrm{~cm}$. The intercrops during rabi season were also sown along with citronella as per treatment to maintain the row ratio of $2: 2$. The rabi crop Mustard was harvested on 24 March 2015 respectively.

The citronella herbs were harvested during the experimental period on 17 December
2014. After harvesting of citronella herbs, distillation was done for oil extraction.

Organic matter and available nitrogen is highest in mustard sole and citronella: mustard intercropping with all three fertility levels i.e. $100 \%, 75 \%$ and $50 \%$ RDF, respectively. The available phosphorus $\left(\mathrm{P}_{2} \mathrm{O}_{5}\right)$ was highest in citronella: mustard intercropping system with $100 \%$ and $75 \%$ RDF fertility level, respectively.

The available of potash was decreased year by year but the highest potash was found in citronella sole. $\mathrm{pH}$ value in sole citronella and intercropping of citronella with mustard different fertility levels decreases yearly. 
Cultivation of citronella sole crop was superior over sole mustard cropping system. In intercropping system the highest citronella equivalent oil yield was found in citronella: Mustard $100 \% \mathrm{RDF}$ followed by $75 \% \mathrm{RDF}$ treatment, respectively.

The highest net return was found in sole citronella system because $\mathrm{B}$ : $\mathrm{C}$ ratio is 4.56 followed by $\mathrm{C}$ : $\mathrm{M}$ with $100 \% \mathrm{RDF}$ intercrop system with $\mathrm{B}$ : $\mathrm{C}$ ratio

\section{Materials and Methods}

\section{Soil of the experimental field}

The university is situated in to indogangetic alluvial tract of Central Plain Zone of U.P. that is come in agro-climatic zone-V. In order to determine the physio-chemical characteristics and fertility status of experimental field, the soil samples were collected randomly from the six places of the field to the depth of $0-15 \mathrm{~cm}$ with the help of soil agar prior to fertilizer application.

The soil samples of all the places were mixed together to form a composite sample for mechanical and chemical analysis.

The soil analysis was done in the agronomy department of this university. The result of physio-chemical analysis is given in tables 1 and 2.

\section{Mechanical analysis}

The mechanical analysis of the soil of experimental field was done by "International Pipette Method" as described by Wright (1939). The results thus obtained have been presented in table 1. According to triangle method of soil classification given by Lyon et al., (1952) and recognized by International Society of Soil Science, the soil may textually be classified as sandy loam.

\section{Chemical analysis}

The original soil sample used in mechanical analysis was also used to analyzed available nitrogen, available phosphorus and available potash as well as for organic carbon, soil $\mathrm{pH}$, electrical conductivity (E.C.) by the method indicated in table 2. It is clear from the Tables 1 and 2 that the soil of the experimental field was sandy loam in texture, low in organic carbon and low in available nitrogen, medium in available phosphorus and medium in available potassium respectively.

Value of $\mathrm{pH}$ showed that the experimental field was slightly alkaline in nature.

\section{Cropping history of the experimental field}

The crops grown in the field affects its productivity and potentialities to a great extent because of difference in the uptake pattern of the nutrients by them. So that before starting the present investigation the cropping history of the experimental field for last five years was carefully examined and has been summarized in table 3 .

\section{Application of fertilizer}

After making the individual experiment unit recommended dose of fertilizer as per treatment was supplied through Urea, DAP and MOP.

The full dose of $\mathrm{P}_{2} \mathrm{O}_{5}, \mathrm{~K}_{2} \mathrm{O}$ and half dose of nitrogen was supplied at the time of sowing and remaining dose of nitrogen was applied in split doses. The details are given in table 4 .

\section{Seed and sowing/ planting}

\section{Citronella}

Root slips of Citronella variety BIO - 13 were used. After removing upper sheath the root 
slips was transplanted in line on 30 July, 2010 at a spacing of $60 \times 60 \mathrm{~cm}$. In the year 2014 the row ratio of $2: 2$ were maintained in citronella intercrop plots.

\section{Mustard}

Seed of Mustard C.V. Urvasi was used @ 5 $\mathrm{kg} / \mathrm{ha}$. The crop was sown with the help of Desi plough in line on 19 October, 2014 at a spacing of $40 \times 20 \mathrm{~cm}$.

\section{Irrigation}

The crop was sown or transplanted after presowing irrigation. The details of irrigation are given in table 5 .

\section{Intercultural operation}

In order to protect the crop from adverse effects of weeds and to pulverize the soil, the weeding and hoeing operation was performed after first and second irrigation at optimum soil moisture condition of the soil by manual labour with the help of khurpi during the experimentation time. In mustard, to maintain plant spacing thinning is done at 20 DAS to maintain plant to plant distance of $15 \mathrm{~cm}$.

\section{Harvesting and distillation of citronella herbs}

The number of harvests, which can be taken during a year depends upon the growth of the plants. The leaves are ready for harvest about 5- 6 months after planting, $20 \mathrm{~cm}$ above the ground level.

The second and subsequent harvests can be taken thereafter at 2.5-3.0 months interval. Distillation was done by the process of steam distillation. The distillation equipment consists of a boiler in which steam is produced, a distillation tub for distilling the grass, a condenser and separators.

\section{Observations recorded during experiment}

\section{Citronella}

All the observations taken during experimental period are as follows:-

\section{Plant population}

In Sole and Intercrop plots, Citronella root slips were already transplanted at $60 \times 60 \mathrm{~cm}$. to maintain the 2:2 row ratio. Plant population was studies individual in each plot at harvest stage.

\section{Number of tillers/plant}

The number of tillers in all the 05 plants were counted at harvest stage and the average number of tillers / plant were worked out, mean values were expressed on plant basis.

\section{Plant height}

Plant height was measured in $\mathrm{cm}$ from the ground level to tip of the plant at harvest stage.

\section{Herbage yield and distillation}

For herbage yield of citronella treatment wise plant was cut with the help of sickles through manual labour from $10 \mathrm{~cm}$ above the ground level from each net plot.

After cutting of herbage bundle were pre pared for fresh green yield.

\section{Distillation}

For distillation, treatment wise herb was collected in distillation tank and through steam distillation process mixture of oil and water were collected in separation unit. Oil was separated from the separator unit and amount of oil was calculated in liter/ha. 


\section{Mustard}

All the observations taken during experimental period are as follows:-

\section{Plant population $/ \mathrm{m}^{2}$}

The plant population of each treatment was recorded twice before thinning and at harvesting stage. For this purpose, one meter scale was placed randomly in 2 places in each plot before thinning and at harvesting stage. In marked places, plants were counted for both initial and final plant population.

The total sum of plant was divided by 2 to get number of plant $/ \mathrm{m}^{2}$ was recorded.

\section{Plant height $(\mathbf{C m})$}

Plant height was measured in $\mathrm{cm}$ from the ground level to tip of the plant at 50 DAS and 100 DAS. For plant height 05 plant were selected and the mean value were used for statistical analysis purpose.

\section{Number of branches per plant}

The sum of total number of branches are counted from 05 selected plant and average number of branches calculated per plant on mean basis for statistical analysis.

\section{Number of silique / plant}

Total numbers of Silique were counted from each selected plants and average value was worked out for statistical analysis.

\section{Biological yield}

After harvesting, the weight of total biomass from each net plot was recorded and after sun drying for five days, the biological yield was converted in to quintals per hectare by multiplying the factor.

\section{Grain yield}

After threshing, winnowing and cleaning the grain yield of each net plot was weighed. The values were converted in to quintals per hectare, by multiplying the factor.

\section{Crop Equivalent Yield (CEY)}

Crop equivalent yield was calculated by following formula

Intercrop yield $\left(\mathrm{kgha}^{-1}\right) \mathrm{x}$ Price of (Rs kg)

$\mathrm{CEY}=$

Price of main crop $\left(\mathrm{Rskg}^{-1}\right)$

\section{Land Equivalent Ratio (LER)}

Land equivalent ratio is the relative land area under sole crops i.e. required to produce the yield achieved in inter cropping.

In the present experiment the LER was estimated by following formula/equations.

\section{Benefit: cost ratio}

Benefit cost ratio was calculated by the following formula.

Benefit cost ratio = $=\frac{\text { Net return }}{\text { Cost of cultivation }}$

\section{Experimental findings}

The present experiment entitled "Response of fertility levels in Citronella (Cymbopogon winterianus L.) Intercropping with Mustard (Brassica juncea)" has been arranged under the following appropriate heads:

To find out most suitable fertility dose for intercrops.

To find out the best economic combination of intercropping 
To asses economics of different fertility levels, and

\section{Response of treatment combination on soil health}

Data recorded regarding soil health, chemical analysis of soil was done treatment wise and presented in table 6 . It is clear from that among sole treatment highest soil organic carbon and available nitrogen is found in sole potato followed by mustard sole treatment.

In intercropping combination highest organic carbon and available Nitrogen found in $\mathrm{C}+\mathrm{M}$ (100\%RDF) followed by C: P (50\% RDF) treatment. The lowest organic carbon and available nitrogen was found in sole citronella treatment.

The available phosphorus $\left(\mathrm{P}_{2} \mathrm{O}_{5}\right)$ was highest in Citronella+ Mustard intercropping system with $100 \%$ followed by $75 \%$ RDF fertility level is $18.40 \mathrm{~kg} / \mathrm{ha}$ Among the sole treatments the lowest availability as phosphorus was found in citronella sole i.e. $17.35 \mathrm{~kg} / \mathrm{ha}$.

The highest available potash $\left(179 \mathrm{~kg}^{-1}\right)$ was found in citronella sole i.e. $179 \mathrm{~kg} / \mathrm{ha}$ and among the intercropping treatments, the highest avalibility was found in $\mathrm{C}+\mathrm{M} 100 \%$ RDF $(178.90 \mathrm{~kg} / \mathrm{ha})$ followed by $75 \% \mathrm{RDF}$ $(178.00 \mathrm{~kg} / \mathrm{ha})$. The data related to $\mathrm{pH}$ value, indicated that the $\mathrm{pH}$ value is lowest in citronella sole treatment. The trend of E.C. was constant in most of the treatments.

\section{Results and Discussion}

\section{Main crop of citronella}

\section{Growth parameter}

Data recorded regarding number of plant / plot and number of tillers / plant at the time of cutting are presented in table 7 and illustrated through figure 4.1.

Data presented in table 7 showed that the significantly highest number of tillers/plant (64.00) was recorded in the Citronella sole treatment. Among the intercropping treatment significantly C+M 100\% RDF (59.12) gave the maximum number of tiller and the minimum number of tillers 53.07 was found in $\mathrm{C}+\mathrm{M}(50 \% \mathrm{RDF})$. The highest number of plant/plot found in citronella sole which was significantly effect the plant population of intercrop citronella.

\section{Leaf length and herbage yield of Citronella}

Data presented in table 8 and illustrated through figure 4.2 showed that the significantly highest leaf length $(73.27 \mathrm{~cm}$.) and herbage yield $(113.93 \mathrm{q} / \mathrm{ha})$ was obtained in citronella sole treatment and lowest herbage yield as recorded in C: M 50\% RDF $(58.19 \mathrm{q} / \mathrm{ha})$ and leaf length $(70.60 \mathrm{~cm}$.$) .$ Among the intercropping system the highest herbage yield was recorded in $\mathrm{C}+\mathrm{M} 100 \%$ $\mathrm{RDF}$ which are significantly superior over all other intercropping treatments.

\section{Intercropping of mustard}

\section{Plant population}

Data recorded before thinning and after thinning for plant population were analyzed and presented in table 9 and illustrated by figure 4.3. The plant population recorded before thinning and after thinning has showed significant differences among the treatments. Numerically the highest plant population before thinning $\left(22 \mathrm{~m}^{2}\right)$ and after thinning $\left(18.5 / \mathrm{m}^{2}\right)$ was recorded in sole Mustard and the lowest plant population recorded in before thinning $\left(20.50 \mathrm{~m}^{-2}\right)$ and after thinning (15.50 $\mathrm{m}^{-2)}$ in $\mathrm{C}+\mathrm{M}$ treatment with $50 \% \mathrm{RDF}$. 


\section{Growth parameter}

Data regarding plant height was recorded at 60 and 120 DAS of crop were analyzed and presented in table 10 (a) and also illustrated by figure 4.4 Data showed that significantly highest plant height recorded at 60 and 120 DAS $(97.05 \mathrm{~cm}$. and $129.60 \mathrm{~cm}$.) in mustard sole plot followed by C+M 100\% RDF (93.20 $\mathrm{cm}$. and $126.60 \mathrm{~cm}$.) respectively. The lowest plant height $(90.10 \mathrm{~cm}$.) was recorded in $\mathrm{C}+\mathrm{M}$ of the $50 \%$ RDF at 120 DAS was the lowest plant height was recorded in $\mathrm{C}+\mathrm{M} 50 \% \mathrm{RDF}$ (120.75 cm.) respectively. Data regarding number of branches and silique per plant were recorded, analyzed and presented in table 11 and illustrated by figure 4.5 .

Data showed that the significantly highest number of branches (8.97) and silique per plant (533.75) has been recorded in mustard sole plant with $100 \%$ RDF followed by $\mathrm{C}+\mathrm{M}$ with $100 \%$ RDF (7.27 and 518.0) respectively. The lowest branches and silique/plant, (6.10) and (471.25) recorded in C: M (50\%RDF) plot, respectively.

\section{Yield and harvest index}

Data regarding biological yield $\left(\mathrm{qha}^{-1}\right)$, grain yield $\left(\mathrm{qha}^{-1}\right)$ and harvest index $(\%)$ were recorded, analyzed and presented in table 12 and also illustrated through figure 4.6.

Data regarding biological yield, grain yield and harvest index indicated the significantly differences among the treatments. The highest biological yield (163.58 q/ha) and grain yield $(24.90 \mathrm{q} / \mathrm{ha})$ were recorded in $\mathrm{C}$ : $\mathrm{M}$ (100\%RDF) which was significantly superior over all treatments followed by mustard sole and $\mathrm{C}+\mathrm{M} 75 \% \mathrm{RDF}$.

The lowest biological yield (117.75 q/ha) and grain yield (20.83 q/ha) was recorded in $\mathrm{C}+\mathrm{M}$ with $50 \%$ RDF treatments.

\section{Yield of Citronella herbs and Citronella equivalent yield}

The data pertaining to original yield of Citronella and Mustard to given in table 13. Data on Citronella equivalent oil yield (kg/ha) as influenced by cropping systems have been summarized in table 13.

Results indicate that different cropping systems were found to exhibit significantly variations in Citronella equivalent oil yield. The significantly highest Citronella equivalent oil yield was found in citronella sole, in inter cropping system highest equivalent yield found in C: M 100\% RDF followed by C: M 75\% RDF respectively.

\section{Economic analysis}

The economics of different fertilizer ratio treatments of sole crop and intercropping $\mathrm{C}$ : $\mathrm{M}(100 \% \mathrm{RDF}),(75 \% \mathrm{RDF})$ and $(50 \% \mathrm{RDF})$ in rabi season was worked out in the form of cost of cultivation. Gross return, net profit and benefit cost ratio and LER. were represented in table 14.

\section{Gross income}

The data computed regarding gross income showed that the highest gross income was found in Citronella sole (Rs.1,02,000) followed by $\mathrm{C}+\mathrm{M}$ intercropping system the highest gross income was found in $100 \%$ RDF (Rs.75945) followed by 75\% RDF (Rs.69601). The lowest gross income was found in mustard sole (Rs.59841).

\section{Net income}

The data pertaining to net income rupees per hectare received under different treatments were summarized in table 14. It is clear from table that the highest net income was obtained 
in sole citronella system in compression to other treatments. In intercropping treatment the highest and lowest net income was obtained in C+M100\% RDF (Rs.55252.92) and mustard sole (39952.82).

\section{Land Equivalent Ratio (LER)}

Land equivalent ratio is the relative land area under sole crops i.e. required to produce the yield achieved in inter cropping. Table 14 showed that the highest LER found in $\mathrm{C}+\mathrm{M}$ $100 \%$ RDF (1.30) followed by $\mathrm{C}+\mathrm{M} 75 \%$ RDF (1.19).

The present experiment entitled "Response of fertility levels in citronella (Cymbopogon winterianus L.) Intercropping with Mustard (Brassica juncea) "was conducted during rabi season 2014-15 at students Instructional Farm (SIF), C.S. Azad University of Agriculture and Technology, Kanpur with an object to find out optimum dose of intercropping and economical fertility levels of rabi intercrops with citronella (Cymbopogon winterianus).The experiment was laid out in Randomized block design with 09 cropping systems treatments with different combination [sole citronella, sole mustard, citronella + mustard $(100 \%$ RDF), citronella + mustard (75\% RDF), citronella + mustard (50\% RDF) each replicated 4 time. Sole treatment with $100 \%$ RDF treated as control.

The soil of experimental field was slightly alkaline with $8.09 \mathrm{pH}$ and $0.21 \mathrm{EC}$. The soil is low in organic carbon and low in available nitrogen $(260 \mathrm{~kg} / \mathrm{ha})$, medium in available phosphorus (17.55 kg/ha) and medium in potash $(175 \mathrm{~kg} / \mathrm{ha})$. The citronella crop (cv. Bio-13) was transplanted in 30 July, 2010 at $60 \times 60 \mathrm{~cm}$. The rabi crop Mustard (cv. Urvasi) was sown 19 October 2014 at 40 x 20 $\mathrm{cm}$. The intercrops during rabi season were also sown along with citronella as per treatment to maintain the row ratio of $2: 2$. The citronella herbs were harvested during the experimental period on 17 December 2014, respectively. After harvesting of citronella herbs, distillation was done for oil extraction. The observation taken at appropriate time and data was statistically analyzed and interpreted.

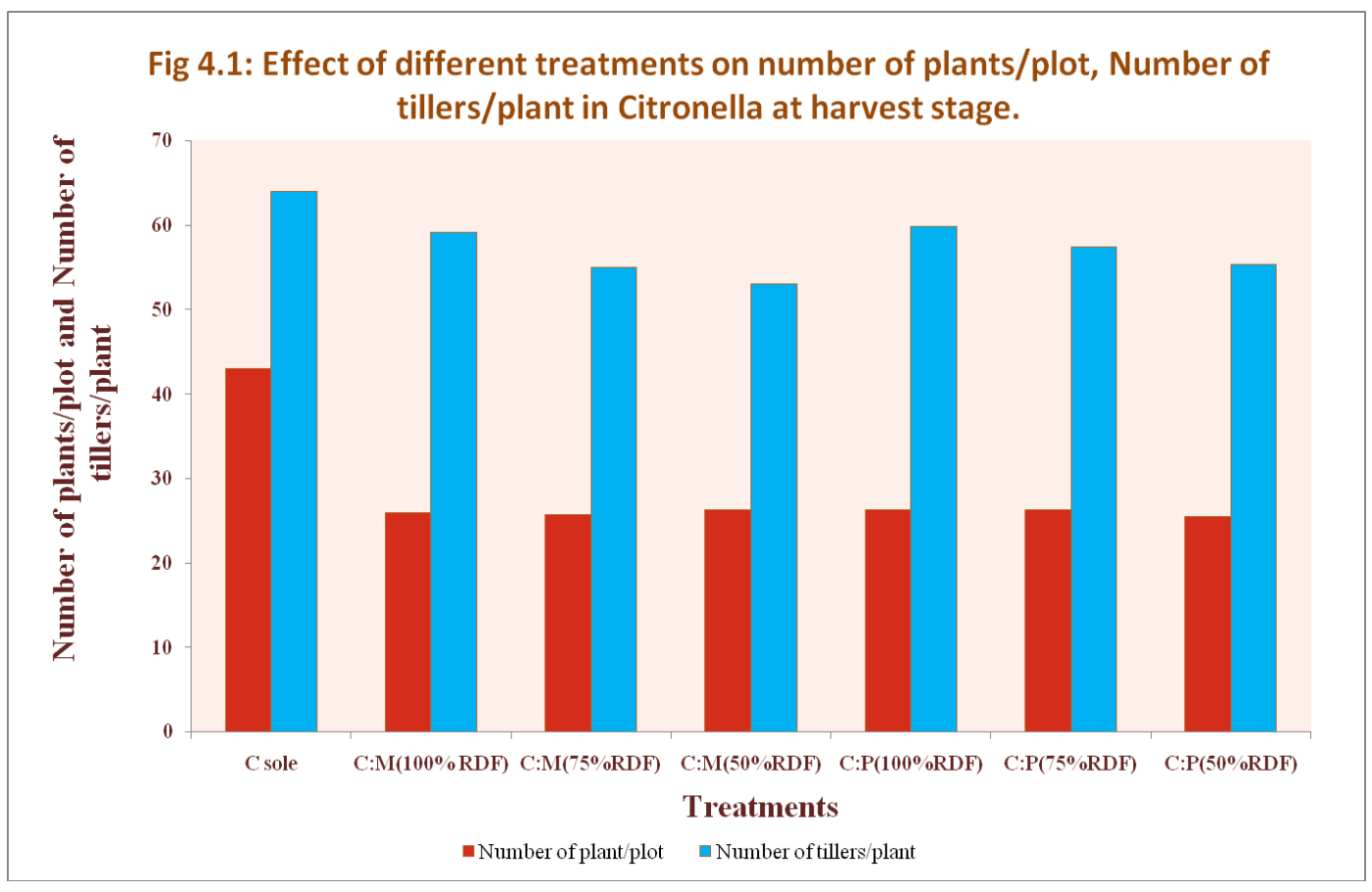


Fig4.2: Effect of different treatments on leaf length and herbage yield of Citronella at harvest stage.

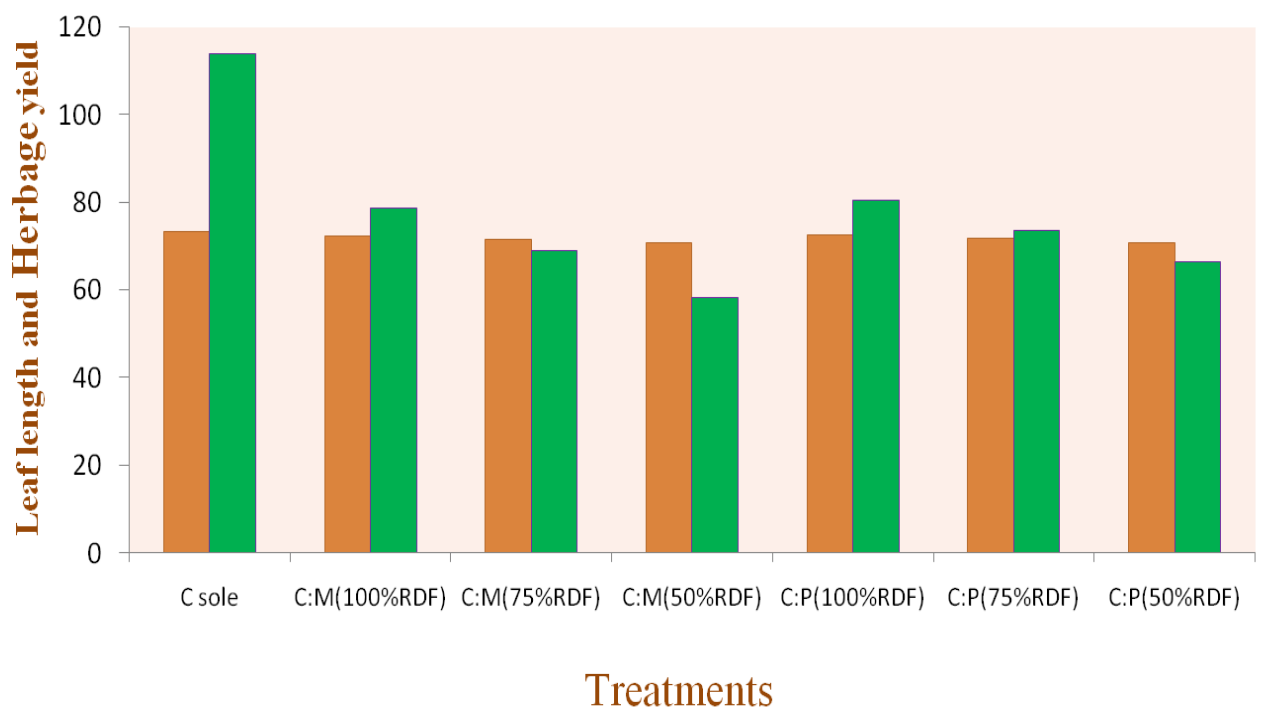

$\square$ Leaf length $(\mathrm{cm}$.$) \quad Herbage yield (\mathrm{Q} / \mathrm{hec})$

Fig 4.3: Effect of different treatments on plant population of mustard

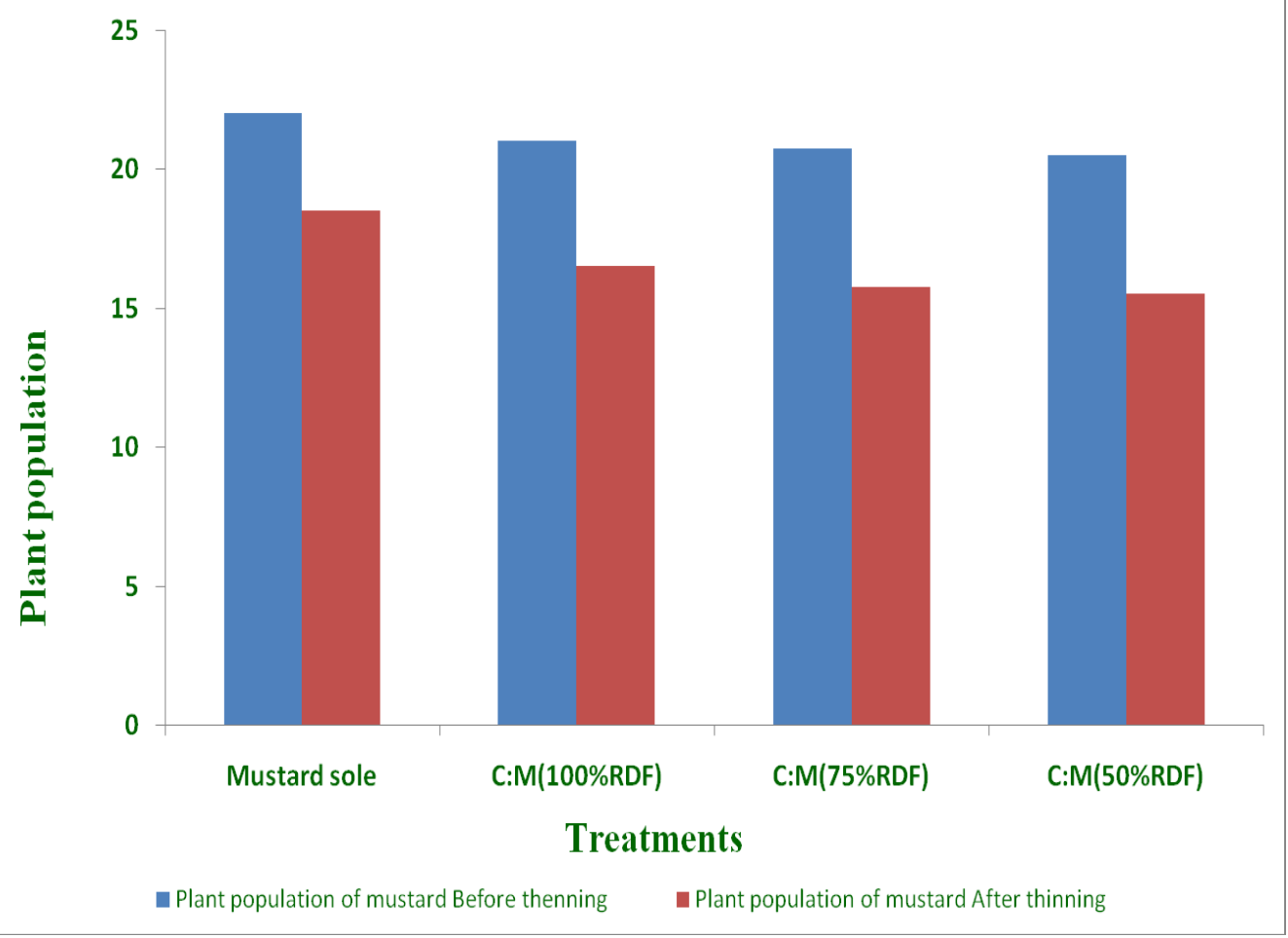



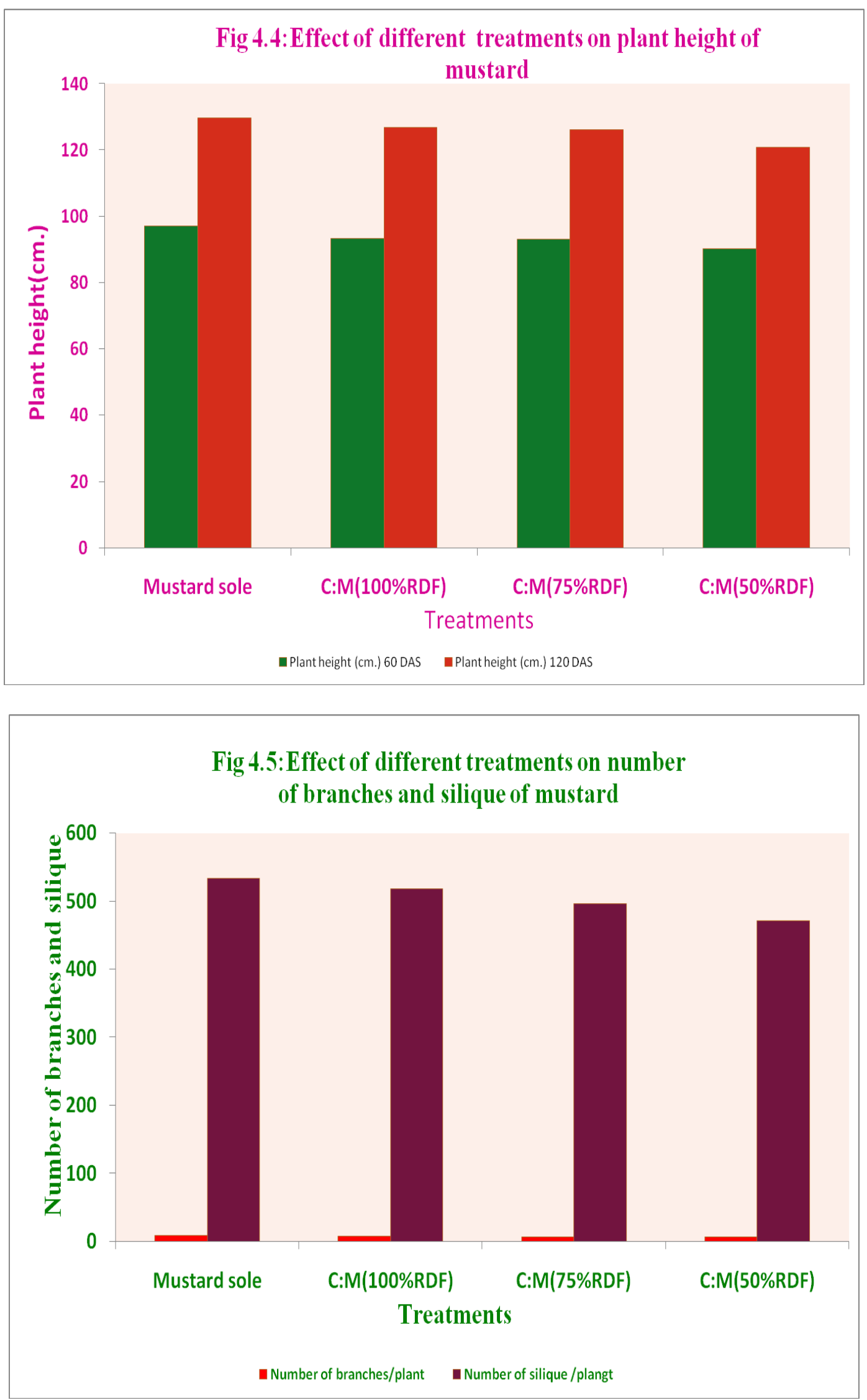


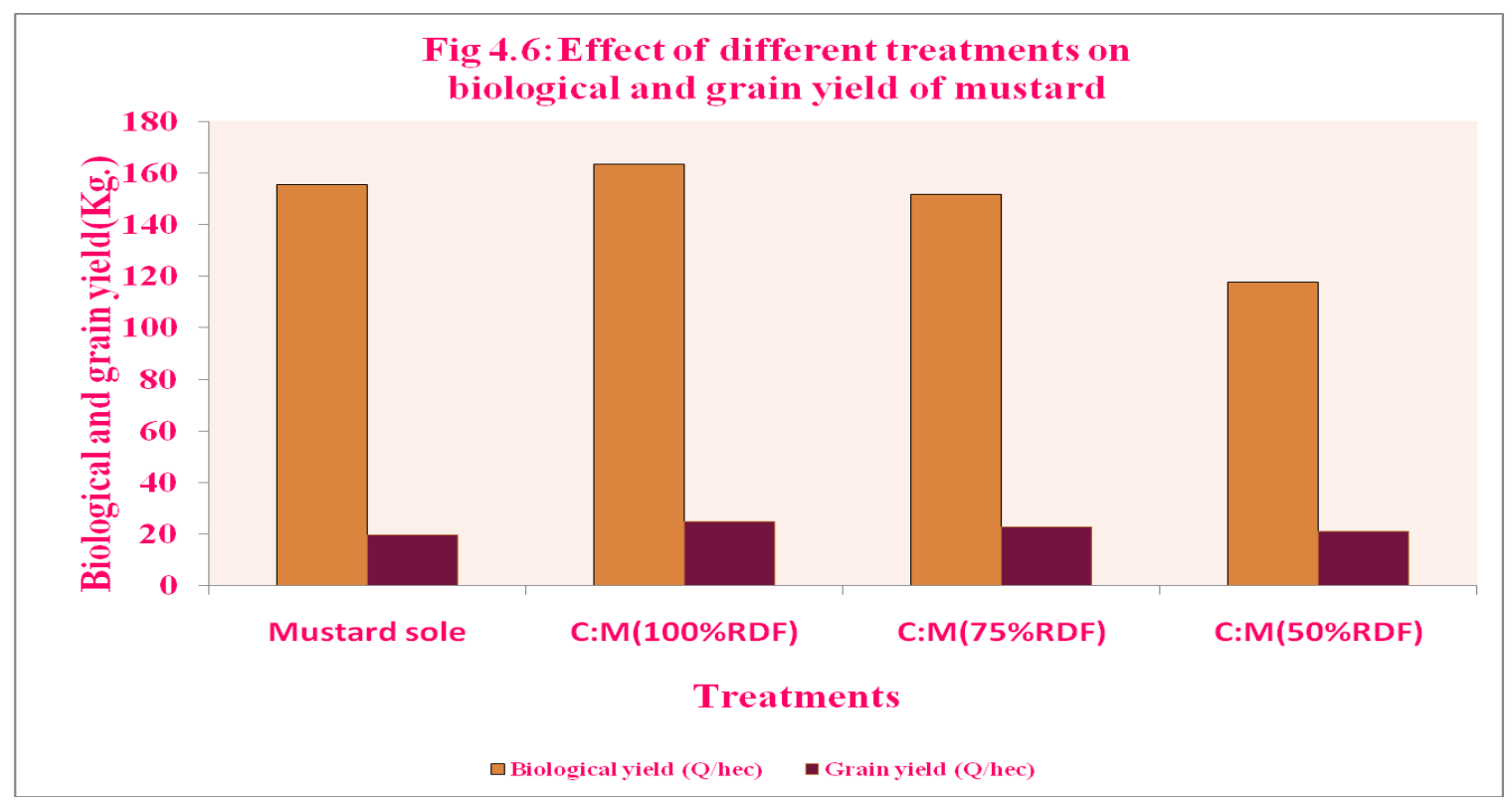

Table.1 Mechanical analysis of the soil of the experimental field

\begin{tabular}{|c|l|c|c|l|}
\hline S.No. & $\begin{array}{c}\text { Soil } \\
\text { characteristics }\end{array}$ & $\begin{array}{c}\text { Values } \\
(\mathbf{\%})\end{array}$ & $\begin{array}{c}\text { Field } \\
\text { No. }\end{array}$ & Method of determination \\
\hline$(1)$ & Sand & 54.30 & 03 & International pipette method \\
\hline$(2)$ & Silt & 21.10 & 03 & International Pipette method \\
\hline$(3)$ & Clay & 20.11 & 03 & International Pipette method \\
\hline$(4)$ & Textural class & Sandy loam & Triangular method \\
\hline
\end{tabular}

Table.2 Chemical analysis of the soil of the experimental field

\begin{tabular}{|c|c|c|c|c|c|c|}
\hline \multirow[t]{2}{*}{ S.No. } & \multirow{2}{*}{$\begin{array}{c}\text { Soil } \\
\text { characteristics }\end{array}$} & \multicolumn{3}{|c|}{ Values (\%) } & \multirow{2}{*}{$\begin{array}{c}\text { Method of } \\
\text { determination }\end{array}$} & \multirow[t]{2}{*}{ Remark } \\
\hline & & 2012 & 2013 & 2014 & & \\
\hline 1 & $\begin{array}{l}\text { Organic carbon } \\
(\%)\end{array}$ & 0.41 & 0.40 & 0.40 & $\begin{array}{l}\text { Black's and } \\
\text { Jackson method } \\
\text { (1973) }\end{array}$ & Low \\
\hline 2 & Soil $\mathrm{P}^{\mathrm{H}}$ & 8.11 & 8.10 & 8.09 & $\begin{array}{l}\text { Electro metric } \\
\text { glass meter } \\
\text { (Piper, 1950) }\end{array}$ & $\begin{array}{l}\text { Slightly } \\
\text { alkaline }\end{array}$ \\
\hline 3 & $\begin{array}{l}\text { E.C. }(\mathrm{mmhos} / \mathrm{cm} \\
\left.\text { at } 25^{\circ} \mathrm{C}\right)\end{array}$ & 0.21 & 0.21 & 0.21 & $\begin{array}{l}\text { E.C. Bridge } \\
\text { (Richard, 1954) }\end{array}$ & Normal \\
\hline 4 & $\begin{array}{l}\text { Available } \\
\text { nitrogen }(\mathrm{kg} / \mathrm{ha})\end{array}$ & 258.60 & 259 & 260 & $\begin{array}{l}\text { Alkaline } \\
\text { potassium per } \\
\text { magnate } \\
\text { method } \\
\text { (Subbaiah and } \\
\text { Asija, 1954) }\end{array}$ & Low \\
\hline 5 & $\begin{array}{l}\text { Available } \\
\text { phosphorus } \\
\text { (kg/ha) }\end{array}$ & 17.60 & 17.50 & 17.55 & Olsen's method & Medium \\
\hline 6 & $\begin{array}{l}\text { Available potash } \\
(\mathrm{kg} / \mathrm{ha})\end{array}$ & 176.50 & 176 & 175 & $\begin{array}{l}\text { Flame } \\
\text { photometer } \\
\text { (Jackson, 1973) }\end{array}$ & Medium \\
\hline
\end{tabular}


Table.3 Cropping history of the field during 2009-2010 to 2014-2015

\begin{tabular}{|c|c|c|c|c|}
\hline S.No. & Year & Kharif & Rabi & Zaid \\
\hline 1 & $2009-10$ & Paddy & Wheat (Halana) & - \\
\hline 2 & $2010-11$ & $\begin{array}{c}\text { Citronella+ } \\
\text { Pegionpea } \\
\text { Citronella+ Maize }\end{array}$ & $\begin{array}{c}\text { Citronella+ Pegionpea } \\
\text { Citronella+ Lentil }\end{array}$ & - \\
\hline 3 & $2011-12$ & $\begin{array}{c}\text { Citronella+Maize } \\
\text { Citronella+ } \\
\text { Pegionpea }\end{array}$ & $\begin{array}{c}\text { Citronella+Mustard } \\
\text { Citronella+ Pegionpea }\end{array}$ & - \\
\hline 4 & $2012-13$ & $\begin{array}{c}\text { Citronella+ } \\
\text { Guar(Fail) } \\
\text { Citronella+ } \\
\text { Maize(Fail) }\end{array}$ & $\begin{array}{c}\text { Citronella+ Mustard } \\
\text { Citronella+ Lentil }\end{array}$ & - \\
\hline 5 & $2013-14$ & $\begin{array}{c}\text { Citronella+ Bajra } \\
\text { Citronella+ Maize }\end{array}$ & $\begin{array}{c}\text { Citronella+ Mustard } \\
\text { Citronella+ Lentil }\end{array}$ & - \\
\hline 6 & $2014-15$ & Citronella sole & Citronella+ Mustard & - \\
\hline
\end{tabular}

Table.4 Details of Fertilizer Application

\begin{tabular}{|c|c|c|c|c|c|}
\hline \multirow[t]{2}{*}{ S.No. } & \multirow[t]{2}{*}{ Name of crop } & \multicolumn{3}{|c|}{$\begin{array}{c}\text { Recommended dose of } \\
\text { fertilizer }\left(\mathrm{Kg}^{-1}\right)\end{array}$} & \multirow{2}{*}{$\begin{array}{l}\text { Method of fertilizer } \\
\text { application }\end{array}$} \\
\hline & & $\mathbf{N}$ & $\mathbf{P}$ & $\mathbf{K}$ & \\
\hline 1 & Citronella & 150 & 80 & 40 & \\
\hline 2 & Mustard & 80 & 60 & 40 & $\begin{array}{l}1 / 2 \text { dose of } \mathrm{N} \& \text { full } \\
\text { dose of } \mathrm{P} \& \mathrm{~K} \text { was } \\
\text { applied at the sowing } \\
\text { time, remaining nitrogen } \\
\text { given two split doses } \\
\text { after first \& third } \\
\text { irrigation stage. }\end{array}$ \\
\hline
\end{tabular}

Table.5 Detail of Irrigation

\begin{tabular}{|c|c|c|l|}
\hline $\begin{array}{c}\text { Name of } \\
\text { Crop }\end{array}$ & $\begin{array}{c}\text { Number of } \\
\text { irrigation }\end{array}$ & Date of Irrigation & \multicolumn{1}{|c|}{ Stage of Crops } \\
\hline & & $29 / 11 / 2014$, & Vegetative growth. \\
& & $20 / 12 / 2014$, & Vegetative growth. \\
Citronella & 05 & $02 / 01 / 2015$, & Vegetative growth \\
& & $19 / 02 / 2015$, & Vegetative growth \\
& & $29 / 11 / 2014$, & Vegetative growth \\
\hline \multirow{3}{*}{ Mustard } & 03 & $20 / 12 / 2014$, & Vegetative, pre-flowering \& \\
& & $04 / 01 / 2015$. & pod filling stage \\
\hline & & $29 / 11 / 2014$, & Vegetative \& pre-flowering \\
C+M & 03 & $20 / 12 / 2014$, & stage. \\
\hline
\end{tabular}


Table.6 Effect of treatment combination on soil health on rabi 2014-2015

\begin{tabular}{|c|c|c|c|c|c|c|c|c|c|c|c|c|}
\hline \multirow{2}{*}{$\begin{array}{l}\text { Treat } \\
\text { ment }\end{array}$} & \multicolumn{2}{|c|}{$\begin{array}{l}\text { Organic } \\
\text { carbon } \\
(\%)\end{array}$} & \multicolumn{2}{|c|}{$\begin{array}{l}\text { Availabl } \\
\text { e N } \\
\left(\mathrm{kgha}^{-1}\right)\end{array}$} & \multicolumn{2}{|c|}{$\begin{array}{l}\text { Availabl } \\
{\text { e } \mathbf{P}_{2} \mathrm{O}_{5}}^{\left(\mathrm{kgha}^{-1}\right)}\end{array}$} & \multicolumn{2}{|c|}{$\begin{array}{l}\text { Available } \\
\mathrm{K}_{2} \mathrm{O} \\
\left(\mathrm{kgha}^{-1}\right)\end{array}$} & \multicolumn{2}{|c|}{ Soil pH } & \multicolumn{2}{|c|}{$\begin{array}{l}\text { E.C. }(\mathrm{mmh} \\
\text { os/cm at } \\
\left.25^{0} \mathrm{c}\right)\end{array}$} \\
\hline & $\begin{array}{l}20 \\
13- \\
20\end{array}$ & $\begin{array}{l}20 \\
14- \\
20 \\
15 \\
\end{array}$ & $\begin{array}{l}20 \\
13- \\
20\end{array}$ & $\begin{array}{l}20 \\
14- \\
20 \\
15\end{array}$ & $\begin{array}{l}20 \\
13- \\
20\end{array}$ & $\begin{array}{l}20 \\
14- \\
20 \\
15 \\
\end{array}$ & $\begin{array}{l}201 \\
3- \\
201 \\
4\end{array}$ & $\begin{array}{l}201 \\
4- \\
201 \\
5 \\
\end{array}$ & $\begin{array}{l}20 \\
13 \\
20 \\
14 \\
\end{array}$ & $\begin{array}{l}20 \\
14- \\
20\end{array}$ & $\begin{array}{l}201 \\
3- \\
201 \\
4 \\
\end{array}$ & $\begin{array}{l}201 \\
4- \\
201 \\
5 \\
\end{array}$ \\
\hline $\begin{array}{l}\text { Citron } \\
\text { ella } \\
\text { Sole }\end{array}$ & $\begin{array}{l}0.4 \\
2\end{array}$ & $\begin{array}{l}0.4 \\
3\end{array}$ & 25 & 25 & $\begin{array}{l}17 . \\
50\end{array}$ & $\begin{array}{l}17 . \\
35\end{array}$ & 178 & 179 & $\begin{array}{l}8.0 \\
8\end{array}$ & $\begin{array}{l}8.0 \\
0\end{array}$ & 0.21 & 0.21 \\
\hline $\begin{array}{c}\text { Musta } \\
\text { rd } \\
\text { Sole } \\
\end{array}$ & $\begin{array}{l}0.4 \\
8\end{array}$ & $\begin{array}{l}0.4 \\
7\end{array}$ & 25 & 25 & $\begin{array}{l}17 . \\
75\end{array}$ & $\begin{array}{l}17 . \\
56\end{array}$ & $\begin{array}{l}176 \\
.5\end{array}$ & 176 & $\begin{array}{l}8.2 \\
6\end{array}$ & $\begin{array}{l}8.2 \\
5\end{array}$ & 0.21 & 0.21 \\
\hline $\begin{array}{l}\mathrm{C}+\mathrm{M} \\
(\mathbf{1 0 0 \%} \\
\mathrm{RDF})\end{array}$ & $\begin{array}{l}0.4 \\
8\end{array}$ & $\begin{array}{l}0.4 \\
9\end{array}$ & $\begin{array}{l}25 \\
8.5\end{array}$ & $\begin{array}{l}25 \\
8.3\end{array}$ & 18 & $\begin{array}{l}18 . \\
40\end{array}$ & 177 & $\begin{array}{l}178 \\
.90\end{array}$ & $\begin{array}{l}8.2 \\
6\end{array}$ & $\begin{array}{l}8.2 \\
6\end{array}$ & 0.21 & 0.22 \\
\hline $\begin{array}{l}\mathrm{C}+\mathrm{M} \\
(\mathbf{7 5 \%} \\
\mathrm{RDF}) \\
\end{array}$ & $\begin{array}{l}0.4 \\
8\end{array}$ & $\begin{array}{l}0.4 \\
7\end{array}$ & $\begin{array}{l}25 \\
8.5\end{array}$ & $\begin{array}{l}25 \\
9.5\end{array}$ & $\begin{array}{l}18 . \\
10\end{array}$ & $\begin{array}{l}18 . \\
30\end{array}$ & 178 & 178 & $\begin{array}{l}8.2 \\
1\end{array}$ & $\begin{array}{l}8.2 \\
0\end{array}$ & 0.22 & 0.21 \\
\hline $\begin{array}{l}\mathrm{C}+\mathrm{M} \\
\mathbf{( 5 0 \%} \\
\mathrm{RDF}) \\
\end{array}$ & $\begin{array}{l}0.4 \\
6\end{array}$ & $\begin{array}{l}0.4 \\
5\end{array}$ & $\begin{array}{l}25 \\
7\end{array}$ & $\begin{array}{l}25 \\
8\end{array}$ & $\begin{array}{l}17 . \\
50\end{array}$ & $\begin{array}{l}17 . \\
40\end{array}$ & $\begin{array}{l}177 \\
.50\end{array}$ & $\begin{array}{l}177 \\
.10\end{array}$ & $\begin{array}{l}8.1 \\
8\end{array}$ & $\begin{array}{l}8.1 \\
6\end{array}$ & 0.20 & 0.20 \\
\hline
\end{tabular}

Table.7 Effect of different treatments on plant population/plot and Number of tillers / plant in Citronella at harvest stage

\begin{tabular}{|c|c|c|}
\hline Treatment & Number of plant/plot & Number of tillers/plant \\
\hline Citronella sole & $\mathbf{4 3 . 0 0}$ & $\mathbf{6 4 . 0 0}$ \\
\hline C:M(100\% RDF) & $\mathbf{2 6 . 0 0}$ & $\mathbf{5 9 . 1 2}$ \\
\hline C:M(75\% RDF) & 25.75 & 54.97 \\
\hline C:M(50\%RDF) & 26.25 & 53.07 \\
\hline SE(m) \pm & 0.202 & $\mathbf{0 . 1 5 0}$ \\
\hline CD $(5 \%)$ & $\mathbf{0 . 6 0 2}$ & $\mathbf{0 . 4 4 6}$ \\
\hline
\end{tabular}

Table.8 Effect of different treatments on leaf length and herbage yield of Citronella at harvest stage

\begin{tabular}{|c|c|c|}
\hline Treatment & Leaf length(cm.) & $\begin{array}{c}\text { Herbage } \\
\text { yield(Q/ha) }\end{array}$ \\
\hline Citronella sole & 73.27 & 113.93 \\
\hline C:M(100\%RDF) & 72.25 & 78.57 \\
\hline C:M(75\%RDF) & 71.50 & 69.06 \\
\hline C:M(50\%RDF) & 70.60 & 58.19 \\
\hline SE(m) \pm & 0.102 & 0.085 \\
\hline CD $(5 \%)$ & 0.304 & 0.254 \\
\hline
\end{tabular}


Table.9 Effect of different treatments on plant population of mustard $/ \mathrm{m}^{2}$

\begin{tabular}{|c|c|c|}
\hline \multirow{2}{*}{ Treatment } & \multicolumn{2}{|c|}{ Plant population of mustard $/ \mathbf{~ m}^{2}$} \\
\cline { 2 - 3 } & Before thinning & After thinning \\
\hline Citronella sole & - & - \\
\hline Mustard sole & 22.00 & 18.50 \\
\hline C:M(100\% RDF) & 21.00 & 16.50 \\
\hline C:M(75\% RDF) & 20.75 & 15.75 \\
\hline C:M(50\% RDF) & 20.50 & 15.50 \\
\hline SE (m) \pm & 0.151 & 0.111 \\
\hline CD $(5 \%)$ & 0.466 & 0.344 \\
\hline
\end{tabular}

Table.10 Effect of different treatments on plant height of mustard

\begin{tabular}{|c|c|c|}
\hline \multirow{2}{*}{ Treatment } & \multicolumn{2}{|c|}{ Plant height (cm.) } \\
\cline { 2 - 3 } & 60 DAS & 120 DAS \\
\hline Citronella sole & - & - \\
\hline Mustard sole & 97.07 & 129.60 \\
\hline C:M(100\% RDF) & 93.20 & 126.60 \\
\hline C:M(75\%RDF) & 93.05 & 125.97 \\
\hline C:M(50\%RDF) & 90.10 & 120.75 \\
\hline SE(m) \pm & $\mathbf{0 . 1 0 0}$ & $\mathbf{0 . 0 9 8}$ \\
\hline CD(5\%) & $\mathbf{0 . 3 1 1}$ & $\mathbf{0 . 3 0 4}$ \\
\hline
\end{tabular}

Table.11 Effect of different treatments on number of branches and silique of mustard

\begin{tabular}{|c|c|c|}
\hline Treatment & $\begin{array}{c}\text { Number of } \\
\text { branches/plant }\end{array}$ & $\begin{array}{c}\text { Number of silique } \\
\text { /plant }\end{array}$ \\
\hline Citronella sole & - & - \\
\hline Mustard sole & 8.97 & 533.75 \\
\hline C:M(100\% RDF) & 7.27 & $\mathbf{5 1 8 . 0 0}$ \\
\hline C:M(75\% RDF) & 7.00 & 496.50 \\
\hline C:M(50\% RDF) & $\mathbf{6 . 1 0}$ & $\mathbf{4 7 1 . 2 5}$ \\
\hline SE(m) \pm & $\mathbf{0 . 0 6 7}$ & 1.726 \\
\hline CD(5\%) & $\mathbf{0 . 2 0 8}$ & $\mathbf{5 . 3 2 0}$ \\
\hline
\end{tabular}

Table.12 Effect of different treatments on biological and grain yield of mustard

\begin{tabular}{|c|c|c|c|}
\hline Treatment & $\begin{array}{c}\text { Biological yield } \\
(\mathbf{Q} / \text { ha })\end{array}$ & $\begin{array}{c}\text { Grain yield } \\
(\mathbf{Q} / \text { ha })\end{array}$ & $\begin{array}{c}\text { Harvest } \\
\text { index(H.I. })\end{array}$ \\
\hline Citronella sole & 113.93 & $\mathbf{8 3 . 0 3 ( O i l ~ y i e l d ) ~}$ & 72.87 \\
\hline Mustard sole & 155.49 & 19.62 & 12.61 \\
\hline C:M(100\%RDF) & 163.58 & 24.90 & 15.22 \\
\hline C:M(75\% RDF) & 151.81 & 22.82 & 15.03 \\
\hline C:M(50\% RDF) & 117.75 & $\mathbf{2 0 . 8 3}$ & 17.69 \\
\hline SE(m) \pm & $\mathbf{0 . 1 1 1}$ & $\mathbf{0 . 0 2 6}$ & $\mathbf{0 . 0 0 2}$ \\
\hline CD $(5 \%)$ & $\mathbf{0 . 3 4 4}$ & $\mathbf{0 . 0 8 2 6}$ & $\mathbf{0 . 0 0 8}$ \\
\hline
\end{tabular}


Table.13 To study the intercropping systems on original yield of Citronella (herbs yield), Mustard and Potato (qha ${ }^{-1}$ )

\begin{tabular}{|c|c|c|c|c|}
\hline $\begin{array}{c}\text { Cropping } \\
\text { system }\end{array}$ & $\begin{array}{c}\text { Citronella } \\
\text { (herb yield }_{\text {qha-1 }^{-1}}\end{array}$ & $\begin{array}{c}\text { Mustard } \\
\text { (grain yield }_{\text {qha-1 }^{-1}}\end{array}$ & $\begin{array}{c}\text { Potato } \\
\text { (tuber } \\
\text { yield qha } \\
\text { 1) }\end{array}$ & $\begin{array}{l}\text { Equivalent } \\
\text { oil yield (kg } \\
\text { ha-1 }^{-1}\end{array}$ \\
\hline Citronella sole & 113.93 & & & 83.03 \\
\hline Mustard sole & & 19.62 & & 49.86 \\
\hline $\begin{array}{c}\text { C:M } \\
\text { (100\% RDF) }\end{array}$ & 78.57 & 24.90 & & 63.28 \\
\hline $\begin{array}{c}\text { C:M } \\
\text { (75\% RDF) }\end{array}$ & 69.06 & 22.82 & & 58.00 \\
\hline C:M (50\% RDF & 58.19 & 20.83 & & 52.94 \\
\hline
\end{tabular}

Table.14 Cost of cultivation, Gross returns, Net returns, B: C ratio and LER

\begin{tabular}{|l|c|c|c|c|c|}
\hline \multicolumn{1}{|c|}{ Treatments } & $\begin{array}{c}\text { Cost of } \\
\text { cultivation }\end{array}$ & $\begin{array}{c}\text { Gross } \\
\text { returns } \\
\text { (Rs/ha) }\end{array}$ & $\begin{array}{c}\text { Net } \\
\text { returns } \\
\text { (Rs/ha) }\end{array}$ & $\begin{array}{c}\text { B: C } \\
\text { ratio }\end{array}$ & LER \\
\hline Citronella & 18340 & 102000 & 83660 & 4.56 & 1.00 \\
\hline Mustard & 19888.82 & 59841 & 39952.82 & 2.008 & 1.00 \\
\hline C:M (100\%RDF) & 20692.08 & 75945 & 55252.92 & 2.67 & 1.30 \\
\hline C:M (75\%RDF) & 19826.95 & 69601 & 49774.05 & 2.51 & 1.19 \\
\hline C:M(50\%RDF) & 19154.32 & 63531.50 & 44377.18 & 2.31 & 1.08 \\
\hline
\end{tabular}

\section{Land Equivalent Ratio (LER)}

\begin{tabular}{|l|lll|l|}
\hline \multirow{2}{*}{$\begin{array}{l}\text { (i) LER of } \\
\text { Mustard }=\end{array}$} & $\begin{array}{l}\text { Yield of citronella in inter } \\
\text { cropping }\end{array}$ & $\begin{array}{l}\text { Yield of citronella in sole } \\
\text { cropping }\end{array}$ & $+\begin{array}{l}\text { Yield of mustard in } \\
\text { inter cropping }\end{array}$ \\
\cline { 2 - 3 } & $\begin{array}{l}\text { Yield of mustard in } \\
\text { sole cropping }\end{array}$ \\
\hline
\end{tabular}

\section{Effect on soil health}

Organic matter highest in mustard sole treatment, the available phosphorus $\left(\mathrm{P}_{2} \mathrm{O}_{5}\right)$ was highest in citronella + mustard $(100 \%$ $\mathrm{RDF})$ followed by $\mathrm{C}+\mathrm{M}(75 \% \mathrm{RDF})$ and mustard sole, respectively. The availability of potash was decreased year by year but the highest potash was found in citronella sole followed by $\mathrm{C}+\mathrm{M} 100 \% \mathrm{RDF}$ in the year 2014-15. $\mathrm{p}^{\mathrm{H}}$ value in sole citronella and intercropping of citronella with mustard under different fertility levels decreases yearly, slowly.

\section{Effect on sole crops}

Citronella sole cropping with $100 \%$ RDF was found to be better than citronella intercropping system with mustard in same proportions in respect to the growth, yield attributes herbage and oil yields of citronella.

In mustard cropping system, C+M (100\% $\mathrm{RDF}$ ) intercropping system was found to be better in respect of yield parameters (Biological and grain yield) over all mustard based treatment. 
Citronella oil equivalent yield (CEY) was significantly higher in sole stand of citronella over sole stand of mustard, as well as their intercropping system with citronella. Citronella sole cropping resulted in higher B: $C$ ratio and net returns over sole Mustard as well as their intercropping system in various fertility combinations.

The lowest weed population was found at harvest stage. The maximum weed density was recorded at pre-sowing stage as compared to later stages. Highest weed population of different weed flora were found motha in citronella sole followed by mustard sole stand treatment.

\section{Effect on rabi intercrops}

Among the different fertilizer ratio of citronella Mustard, highest Leaf length at cutting and number of tillers of citronella was found in citronella sole treatment followed by $\mathrm{C}+\mathrm{M} \quad(100 \% \quad \mathrm{RDF})$.There are significant differences among the intercropping treatments significantly highest herbage yield of citronella was found in citronella sole treatment followed by C:M 100\% RDF.

Plant height recorded at 60 and 120 DAS stage and number of branches/plant at Pod filling stage was significantly highest in mustard sole followed by $\mathrm{C}+\mathrm{M} 100 \%, 75 \%$ and $50 \%$ RDF treatment. Among the other treatment combination of mustard basis highest plant height recorded in mustard sole followed by $\mathrm{C}+\mathrm{M} 100 \%, 75 \%$ and $50 \% \mathrm{RDF}$ treatment. Regarding the yield attributing character like number of silique highest in mustard sole followed by $\mathrm{C}+\mathrm{M} 100 \%, 75 \%$ and $50 \%$ RDF treatment.

Among the intercropping treatments of $\mathrm{C}+\mathrm{M}$ significantly the highest biological yield and grain yield of mustard was recorded in citronella: mustard 100\% RDF followed by $75 \% \mathrm{RDF}$, respectably.

\section{Effect of Land Equivalent Ratio (LER)}

Higher LER in intercropping systems indicated yield advantage over monocropping due to better land utilization. Higher LER values in $\mathrm{C}+\mathrm{M}$ (100\%RDF) intercropping system i.e.1.27 followed by $\mathrm{C}+\mathrm{M}(75 \% \mathrm{RDF})$ intercropping system was recorded. On the basis of experimental result conducted during rabi season (2014-15) at Student Instructional Farm of C.S.A.U.A\&T., Kanpur under irrigated condition following conclusion can be done.

Cultivation of citronella sole crop was superior over sole Mustard as well as their intercropping system adopting in different fertilizer dose. In relation to growth, yield contributing characters and yield of citronella, sole cropping system gave significantly the highest citronella equivalent oil yield than other sole copping system.

\section{Intercropping effect with plant growth and soil health}

Combination with citronella + Mustard intercropping system with $100 \%$ fertility level is better than all other suitable combination intercropping system, respectively.

From economic point of view the highest net return (Rs.83660.00) was found in sole citronella system. But among the intercropping system, intercropping of $\mathrm{C}+\mathrm{M}$ with $100 \% \mathrm{RDF}$ is the next highest benefit treatment (Rs.55252.92) followed by $\mathrm{C}+\mathrm{M}$ 75\% RDF(Rs.49774.05), and C+M 50\% RDF (Rs.44377.18) respectively.

\section{Performance of citronella}

The cropping systems significantly affected the growth attributes (plant population/ plots, Leaf length $(\mathrm{cm})$ and number of tillers/plants) at the cutting time. The higher growth performance in sole crop as compared to 
intercropping system has also been observed by Ansari et al., (2015), Verma et al., (2014), and Singh et al., (2012). It is also clear from the result that next to Citronella sole, $\mathrm{C}+\mathrm{M}$ (100\%RDF) treatment was also recorded significantly superior in the characters like Leaf length $(\mathrm{cm})$ at the cutting time. The intercrop was affected due to the presence of inter and intra-specific competition between main crop and the intercrop (Mustard) for growth resources such as nutrients, moisture and solar radiation due to change in crop geometry as compared to sole crop. The results of the present investigation are in close conformity with the findings of Verma et al., (2014) and Ansari et al., (2012).

Sole citronella recorded higher values for herbage yields than their intercropping with Mustard. This may be due to optimum spacing available for the plants. The higher growth performance in sole crop as compared to intercropping system has also been observed by Ansari et al., (2015) and Verma et al., (2014). The intercrop was affected due to the presence of inter and intra-specific competition between main crop and the intercrop (Mustard) for growth resources such as nutrients, moisture and solar radiation due to change in crop geometry as compared to sole crop. The results of the present investigation are in close conformity with the findings of Ansari et al., (2015) and Mani ram (2014).

\section{Performance of mustard}

The final plant population recorded at harvest stage significantly highest in C+M $(100 \%$ RDF) stand of Mustard followed by $75 \%$ and 50\%RDF Citronella + Mustard intercropping system. Growth parameters of mustard were significantly influenced due to various combinations of cropping systems. The plant height at 60 DAS and 120 DAS recorded significantly higher values in Mustard sole compared to all other intercropping combination. In intercropping system highest height recorded in $\mathrm{C}$ : $\mathrm{M}(100 \% \mathrm{RDF})$ followed by $75 \%$ and $50 \%$ RDF treatment. This might be due to presence of competition between main crop and the intercrop for growth resources such as nutrients, moisture and solar radiation because of exhaustive nature of main as well as intercrops, Verma et al., (2014), kaushik et al., (2001). Number of branches and silique were significantly higher in sole stand of mustard than intercropping system. This could be attributed due to the conditions of plant growth and development for mustard in sole cropping as compared to intercropping system, as also evident in growth attributes. Similar findings were also reported by Verma et al., Chand et al.,(2009), (2014), Kumar et al., (2002). While, the Biological and grain yield of Mustard was influenced significantly by various types of cropping combination of mustard with citronella. The results of present investigation are in close conformity with the findings of Verma et al., (2014). Cropping systems influenced the grain yield as well as biological yield of mustard during the experimentation. This might be due to that changes in planting system could cause variation in grain and Stover yield of mustard at different level of plant geometry and planting pattern. Finally higher growth and yield attributing characters lead to greater grain and Stover yield. Similar results also reported by Verma et al., (2014).

\section{System productivity and economics}

Intercropping systems showed improvement in citronella equivalent oil yield (CEOY), net returns and $\mathrm{B}$ : $\mathrm{C}$ ratio. The result indicates that different cropping system was found to exhibit significantly variations for Citronella equivalent oil yield, economics and increasing in soil organic matter and increase in nitrogen level in combination of citronella + mustard 
intercropping system. The Citronella sole cropping system gave significantly the highest Citronella equivalent oil yield, net returns and $\mathrm{B}$ : $\mathrm{C}$ ratio followed by citronella + mustard $(100 \% \mathrm{RDF})$, Citronella + mustard $(75 \% \mathrm{RDF})$ and Citronella + mustard (50\%RDF) intercropping system. It might be due to less effect of competition in citronella sole stand, which reduces inter-specific competition than intercrops. The maximum among intercropping system citronella + mustard (100\% RDF) recorded significantly higher citronella equivalent oil yield as compared to either of the intercropping system. It was due to similar citronella oil yield under intercropping system as that of its sole stand. The results are in accordance with the findings of Mohammed et al., (2012), Kumar et al., (2013) and Sarkar et al., (2011).

\section{References}

Ansari, M.H.; Ansari, M.A.; Srivastava, AK; Khan, Naushad (2014)-Crop diversification through citronella based cropping system. The Indian Journal of Agricultural Sciences.Vol.84 (12):15557.

Banerjee, Arnab; Datta, Jayanta Kumar; Mondal, Naba Kumar (2010)- Impact of different combined doses of fertilizers with plant growth regulators on growth, yield attributes and yield of mustard (Brassica campestris $\mathrm{cv} . \mathrm{B}_{9}$ ) under old alluvial soil of Birdman, West Bengal, India. Frontiers of Agriculture in China, Volume 4, Issue 3, pp 341-351.
Bhati, A.S. and sherma, S.K. (2005)-Influence of potassium and time of application and leaf area index and chlorophyll content of mustard, Environment and ecology,245 (special-3) 724-725.

Cheema, M.A.; Saleem, M.F.; Muhammad, N.; Wahid, M.A. and Baber, B.H. (2010) - Impact of rate and timing of Nitrogen application on yield and quality of Canola (Brassica napus L.). Pak. J. Bot., 42(3): 1723-1731.

Dabhi, M.K.; Gupta, D.G. and Patel, J.J. (2010)-Response of sulphur application on growth, yield attributes and yields of mustard under middle Gujarat condition. Green farming, 3:272-273.

Gendy, E; Taghred, A.G.; Hegazy, A. and Sayed, E. S.M. (2013)- Effect Of Bio fertilizers And urea On Growth, Yield, Essential Oil And Chemical Compositions Of Cymbopogon Citratus Plants. Journal of Applied Sciences Research, 9(1): 309320, 2013.

Gangwal, T.V.; Patel, M.V.; and Jadav, N.J. (2011)-Effect of phosphorus, sulphur and PSB on Yield, nutrient uptake and soil fertility after harvest of mustard. Indian Journal of Fertilizers, 7(8):3240.

K. Puttanna, NM Nanje Gowda and E.V.S. Prakasa Rao (2001) - Effects of applications of $\mathrm{N}$ fertilizers and nitrification inhibitors on dry matter and essential oil yields of Java citronella (Cymbopogon winterianus Jowitt.). The Journal of Agricultural Science / Volume 136, pp 427-431.

\section{How to cite this article:}

Neeraj Kumar, Mayank Kumar, Arjun Patel, Shasank Rajput and Srivastava, A.K. 2017. Response of Fertility Dose in Citronella (Cymbopogon winterianus L.) Intercropping with Mustard (Brassica juncea). Int.J.Curr.Microbiol.App.Sci. 6(8): 2720-2736. doi: https://doi.org/10.20546/ijcmas.2017.608.326 